\title{
Myopathy and diabetes mellitus
}

INSERM

\section{Source}

INSERM. (1999). Orphanet: an online rare disease and orphan drug data base. Myopathy and diabetes mellitus. ORPHA:2596

A rare, genetic, mitochondrial DNA-related mitochondrial myopathy disorder characterized by slowly progressive muscular weakness (proximal greater than distal), predominantly involving the facial muscles and scapular girdle, associated with insulindependent diabetes mellitus. Neurological involvement and congenital myopathy may be variably observed. 